\title{
Perbedaan Besaran Uang Saku dan Aktivitas Fisik antara Siswi Gemuk dan Normal di SMA Negeri 5 Surabaya
}

\section{The Differences in the Amount of Pocket Money and Physical Activity between Overweight and Normal Students at SMA Negeri 5 Surabaya}

\author{
Annisa Rizka Oktavianita*, Bambang Wirjatmadi
}

\begin{abstract}
ABSTRAK
Latar Belakang: Tingginya konsumsi makanan akibat pengeluaran uang saku berlebih dan rendahnya aktivitas fisik dapat meningkatkan resiko kegemukan.

Tujuan: Untuk menganalisis perbedaan besaran uang saku dan aktivitas fisik antara siswi gemuk dan normal di SMA Negeri 5 Surabaya.

Metode: Penelitian ini menggunakan desain studi case control dengan total responden 52 siswi yang terbagi menjadi dua kelompok yaitu 26 siswi kelompok kasus yaitu siswi gemuk dan 26 siswi kelompok kontrol yaitu siswi normal. Dilakukan pengukuran berat badan menggunakan digital scale dan tinggi badan menggunakan microtoise untuk menilai status gizi, pengukuran ini dilakukan pada saat sebelum penelitian dimulai. Wawancara dan pengisian kuesioner guna mengetahui karakteristik dan besaran uang saku beserta aktivitas fisik responden yang diukur bersamaan pada saat pengambilan data. Teknik analisis data menggunakan uji beda Mann Whitney dengan $p<0,05$.

Hasil: Rata-rata usia siswi pada kelompok kasus adalah 15 tahun sedangkan pada kelompok kontrol adalah 16 tahun. Pekerjaan ayah dari kedua kelompok siswi adalah sebagai karyawan swasta (53,8\% dan 57,7\%) dan wiraswasta (15,4\% dan $19,2 \%)$. Untuk pekerjaan ibu dari kedua kelompok siswi tersebut ialah ibu rumah tangga $(96,2 \%$ dan $92,3 \%)$ dan wirausaha masing-masing kelompok sebesar $3,8 \%$. Hasil uji beda besaran uang saku adalah $p=0,380$ dan hasil dari uji beda aktifitas fisik adalah $\mathrm{p}<0,001$.

Kesimpulan: Tidak terdapat perbedaan besaran uang dan terdapat perbedaan aktivitas fisik antara kelompok kasus dan kontrol. Perlu diadakannya aktivitas fisik tambahan sebagai bentuk pencegahan masalah gizi lainnya.
\end{abstract}

Kata kunci: besaran uang saku, tingkat aktivitas fisik, remaja putri

\section{ABSTRACT}

Background: High food consumption due to spending excess money and low physical activity could increased the risk of overweight.

Objectives: This study aimed to analyzed the differences amount of pocket money and physical activity between students with overweight and normal at SMA Negeri 5 Surabaya.

Methods: The design of the study was case control involving 52 samples with 26 case sampels for overweight students and 26 control sampels for normal students. Body weight measurements using a digital body scale and height using microtoise, this measurements was done before the research began. The quetioners were to identified data identity, amount of pocket money and physical activity. Data were analyzed using Mann Whitney with $p>0.005$.

Results: Some characteristic of the sampels were based on age groups, parent's occupation and body mass index. The average age of case sampels was 15 years old and control sampels was 16 years old. The occupation of sampels father from two groups were as employees (53.8\% and 57.7\%) and entrepreneurs (15.4\% and 19.2\%). Furthermore the occupation of sampel's mother from two groups were as house wife (96.2\% and 92.3\%) and entrepreneurs (3.8\%). The test result showed the $p$ value about difference of amount of pocket money was $p=0.380$ and $p<0.001$ for physical activity. Conclusions: In conclusion there were no differences of amount of pocket money between the two groups. There were differences about physical activity between the two groups .

\section{Keywords: amount of pocket money, physical activity level, adolescent}

*Koresponden:

Annisa Rizka Oktavianita

annisarizkao06@gmail.com

Departemen Gizi Kesehatan,Fakultas Kesehatan Masyarakat, Universitas Airlangga 


\section{PENDAHULUAN}

Masa remaja adalah tahap awal dimulai terjadinya perubahan dari perkembangan psikologi dan kematangan seksual pada seorang individu dari masa anak-anak hingga menjadi dewasa. Tidak hanya perubahan bentuk fisik saja, namun terjadi perubahan psikologis seperti perubahan gaya hidup contohnya pada pola makan yang dapat memperngaruhi status gizi bagi kesehatan pada saat dewasa ${ }^{1}$. Kasus kelebihan berat badan atau overweight di Indonesia masih banyak ditemukan terutama pada kalangan anak-anak, remaja dan juga dewasa. Overweight adalah kedaan seorang individu yang mengalami kenaikan berat badan yang disebabkan oleh tingginya asupan makanan daripada yang dikeluarkan ${ }^{2}$. Hasil prevalensi overweight dan obesitas pada anak dan remaja usia 5-19 tahun adalah $18 \%^{3}$. Prevalensi dari kejadian gizi lebih di Indonesia sebanyak $13,5 \%^{4}$. Data prevalensi gizi lebih pada usia remaja 16-18 tahun di Indonesia yaitu sebanyak 7,3\% yang terbagi menjadi $5,7 \%$ overweight dan $1,6 \%$ merupakan data prevalensi Kota Surabaya mengenai kejadian overweight yaitu sebesar $12,2 \%{ }^{4}$. Menurut hasil prevalensi kasus kegemukan di Jawa Timur yaitu sebesar $11,6 \%$ dimana angka tersebut melebihi angka prevalensi nasional untuk kasus kegemukan ${ }^{5}$. Dari hasil penelitian sebelumnya didapatkan angka prevalensi overweight sebesar $48,5 \%$ pada siswi SMA Negeri 5 Surabaya ${ }^{6}$. Ada beberapa faktor pendukung sehingga terjadinya overweight yaitu kurangnya aktivitas fisik, pola makan berlebih kebiasaan konsumsi makanan tinggi kalori, kurangnya pengetahuan terhadap bahan pangan yang dikonsumsi, luasnya akses untuk dapat membeli bahan pangan dan sosial ekonomi yang mumpuni ${ }^{7}$. Overweight dapat terjadi ketika seorang individu mengonsumsi makanan dengan jumlah kalori yang berlebih dibandingkan yang dibakar. Apabila terjadi ketidak seimbangan energi yang masuk dan yang keluar maka hal ini dapat memicu terjadiya obesitas dan overweight ${ }^{8}$. Uang saku merupakan sejumlah uang yang telah diterima anak dari orang tua mereka dengan tujuan sebagai tunjangan dalam waktu bulan, minggu maupun hari. Tujuan lain diberikannya uang saku tersebut adalah untuk menilai kebiasaan dalam mengalokasikan uang saku tersebut serta memberikan pengalaman realistis dalam mengajarkan anak dalam mengelola keuangannya ${ }^{9}$. Pemberian uang saku juga sebagai alat bantu dalam menilai pola konsumsi pangan seorang individu, semakin besar ataupun tinggi uang saku yang diterima atau yang diberikan maka hal tersebut akan mendukung seorang individu dalam kegiatan mengonsumsi suatu makanan atau minuman, begitu juga sebaliknya ${ }^{10}$. Pada masa remaja meningkatnya resiko seseorang mengalami gizi lebih hingga overweight diakibatkan dari menurunnya aktivitas fisik dan adanya peningkatan untuk mengonsumsi makanan dengan kandungan gizi rendah, tinggi lemak dan juga tinggi akan karbohidrat. Peran sebaya akan semakin nampak ketika seorang individu remaja tersebut mengikuti atau memiliki aktivitas sosial yang tinggi. Selain aktvitas fisik, dua faktor lain yang dapat mempengaruhi status gizi adalah umur dan jenis kelamin ${ }^{11}$. Pemenuhan nutrisi yang cukup diperlukan guna untuk proses pertumbuhan dan perkembangan dimulai dari anak-anak, remaja dewasa sampai lansia, namun pada aktivitas fisik dengan semakin banyak atau seringnya tubuh untuk melakukan gerakan aktivitas hal tersebut dapat mengeluarkan energi yang terdapat di dalam tubuh ${ }^{12}$.

Penelitian ini dilakukan dengan tujuan untuk menganalisis perbedaan besaran uang saku dan aktivitas fisik antara siswi gemuk dan normal di SMA Negeri 5 Surabaya. Pemilihan lokasi pada sekolah ini dikarenakan terdapat prevalensi terjadinya overweight terutama pada siswinya, selain itu lokasi sekolah yang sangat dekat dengan tempat makan, cafe, mall, pujasera dan terdapat banyak pedagang kaki lima yang menjual makanan maupun berbagai macam minuman dimana hal ini menunjukkan bahwa adanya kemungkinan tingginya aktivitas dalam mengalokasikan uang untuk menggunakannya dalam membeli makanan dan minuman. Pada penelitian sebelumnya ditemukan adanya perbedaan bermakna mengenai aktivitas fisik pada kelompok non overweight dan overweight yang memiliki nilai $p=0.009^{13}$. Salah satu faktor yang dapat mempengaruhi terjadinya overweight yaitu besar uang saku. Dengan demikian besar uang saku tersebut dapat mempengaruhi kuantitas dan kualitas jenis makanan yang dikonsumsi ${ }^{14}$.

\section{METODE}

Penelitian ini merupakan penelitian analitik observasional dengan desain studi case control, dimana kelompok kasus adalah siswi gemuk sedangkan pada kelompok kontrol adalah siswi normal. Teknik pengambilan sampel menggunakan simple random sampling dengan total jumlah sampel 52 siswi yang terbagi menjadi 26 siswi pada kelompok kasus dan 26 siswi pada kelompok kontrol. Terdapat beberapa kriteria inklusi bagi para responden pada penelitian ini yaitu siswi kelas X dan XI SMA Negeri 5 Surabaya, dalam keadaan sehat jasmani dan rohani, dan bersedia untuk mengikuti serangkaian penelitian.

Pelaksanaan penelitian dimulai pada bulan Februari hingga April 2019. Variabel bebas dalam penelitian ini adalah besaran uang saku dan aktivitas fisik sedangkan variabel terikat yaitu siswi gemuk dan normal. Pengambilan data dalam penelitian ini adalah dengan mengukur tinggi badan menggunakan microtoise dan berat badan menggunakan digital scale untuk mengetahui status gizi dari setiap responden, selain itu juga dilakukan wawancara mengenai besaran uang saku dan juga gambaran aktivitas fisik yang dilakukan dalam 24 jam terakhir untuk menggambarkan aktivitas fisik harian sehingga dapat ditemukan nilai Total Energi Ekspenditur (TEE), dimana pengukuran ini dilakukan sebelum penelitian dimulai. Instrumen yang digunakan dalam penelitian ini adalah kuesioner data identitas diri untuk memperoleh data mengenai karakteristik responden yaitu usia dan pekerjaan orang tua. Kuesioner aktivitas fisik untuk memperoleh data tingkat aktivitas fisik responden dengan menanyakan aktivitas fisik apa saja yang dilakukan oleh responden dalam waktu 24 jam beserta berapa lama aktivitas tersebut dilakukan untuk mendapatkan gambaran aktivitas fisik dan selanjutnya dapat dihitung BMR (basal metabolic rate), PAL (physical activity level), SDA (specific dynamic action) dan TEE (total energi ekspenditur). Uji statistik menggunakan uji 
perbedaan Mann Whitney dengan $p<0,05$ untuk menganalisis perbedaan besaran uang saku dan aktivitas fisik antara siswi overweight dan tidak overweight. Penelitian ini telah memperoleh izin dari Komisi Etik Fakultas Keperawatan Universitas Airlangga dengan No: 1346-KEPK tanggal 1 April 2019.

\section{HASIL DAN PEMBAHASAN}

Untuk distribusi karakteristik responden terdapat pada tabel 1. Karakteristik pada responden meliputi usia dengan rentang usia 15-17 tahun dimana pada kelompok kasus didominasi oleh kelompok usia 15 tahun sedangkan pada kelompok kontrol didominasi oleh kelompok usia 16 tahun. Ketika seorang individu memasuki usia remaja, maka akan terjadi beberapa perubahan seperti pola makan, rasa ingin bersama dengan teman sebaya lebih besar baik dalam makan bersama, memilih makanan apa yang hendak dikonsumsi, sangat berbeda dengan kelompok orang dewasa yang lebih cenderung memilih sendiri dalam melakukan aktivitas sehari-hari baik dalam kumpul untuk makan bersama atau hal lainnya ${ }^{15}$. Adanya pengaruh dari pekerjaan orang tua terhadap kuantitas dan kualitas dari makanan yang dikonsumsi sangatlah besar ${ }^{16}$. Pada distribusi pekerjaan orang tua responden, di dapatkan bahwa ayah dari kelompok kasus maupun kontrol banyak yang bekerja sebagai karyawan swasta dengan presentase $53,8 \%$ dan $57,7 \%$. Sedangkan pada pekerjaan ibu baik pada kelompok kasus dan kontrol keduanya bekerja dalam kelompok lain-lain yaitu sebagai ibu rumah tangga 96,2\% pada kelompok kasus dan 92,3\% pada kelompok kontrol. Hasil dari penelitian sebelumnya menyatakan tidak terdapat hubungan antara pekerjaan dari ayah dan ibu dengan status gizi responden, hal ini disebabkan karena status gizi merupakan bentuk dampak langsung dari hasil masuknya makanan dengan jangka waktu yang tidak sebentar, maka dari itu yang berperan dalam perubahan status gizi yaitu berasal dari faktor makanan yang dikonsumsi ${ }^{17}$. Pada hasil distribusi status gizi di dapatkan 26 siswi (50\%) gemuk dan 26 siswi (50\%) normal. Beberapa faktor yang dapat memicu terjadinya overweight atau kegemukan yaitu faktor lingkungan seperti aktivitas fisik, jenis makanan, pola makan, porsi makan yang dikonsumsi dalam satu hari ${ }^{18}$.

Pada Tabel 2 menampilkan distribusi besaran uang saku responden. Diketahui bahwa sebanyak 34,6\% siswi pada kelompok kasus memiliki besaran uang saku yang diperoleh adalah Rp 15.000 hingga $<$ Rp 20.000. Pada kelompok kontrol sebanyak $26,9 \%$ siswi banyak mendapatkan uang saku sebesar $<$ Rp 15.000 dan sebanyak $26,9 \%$ siswi memiliki uang saku sebanyak Rp 20.000 hingga $<R p$ 25.000. Dari hasil uji beda ditemukan tidak terdapat perbedaan besaran uang saku antara kelompok kasus dan kontrol dengan nilai $p=0,380$ dengan nilai $O R=1,364$. Semakin tinggi uang saku yang diberikan orang tua kepada anak guna memenuhi kebutuhan sehari-hari maka semakin meningkat pula kegiatan konsumsi dari individu tersebut ${ }^{13}$. Berdasarkan nilai OR dapat disimpulkan bahwa siswi dengan besar uang saku lebih tinggi memiliki resiko 1,364 kali lebih besar untuk mengalami kegemukan. Hasil wawancara kepada para siswi dalam penelitian ini diketahui bahwa uang saku tersebut tidak hanya digunakan untuk membeli makanan ataupun minuman, melainkan untuk membeli keperluan sekolah dan untuk ditabung.

Tabel 1 Distribusi Karakteristik Responden di SMA Negeri 5 Surabaya Tahun 2019

\begin{tabular}{|c|c|c|c|c|}
\hline \multirow{3}{*}{ Karakteristik } & \multicolumn{4}{|c|}{ Jumlah Responden } \\
\hline & \multicolumn{2}{|c|}{ Kasus } & \multicolumn{2}{|c|}{ Kontrol } \\
\hline & $\mathrm{n}$ & $\%$ & $\mathrm{n}$ & $\%$ \\
\hline \multicolumn{5}{|l|}{ Usia } \\
\hline 15 tahun & 11 & 42,30 & 9 & 34,61 \\
\hline 16 tahun & 8 & 30,77 & 15 & 57,69 \\
\hline 17 tahun & 7 & 26,92 & 2 & 7,69 \\
\hline Total & 26 & 100 & 26 & 100 \\
\hline \multicolumn{5}{|l|}{ Pekerjaan Orang } \\
\hline \multicolumn{5}{|l|}{ Tua } \\
\hline \multicolumn{5}{|l|}{ 1. Ayah } \\
\hline Tidak bekerja & 1 & 3,8 & 0 & 0 \\
\hline Wirausaha & 1 & 3,8 & 2 & 7,7 \\
\hline Karyawan swasta & 14 & 53,8 & 15 & 57,7 \\
\hline PNS & 3 & 11,5 & 3 & 11,5 \\
\hline Wiraswasta & 4 & 15,4 & 5 & 19,2 \\
\hline Lain-lain & 3 & 11,5 & 1 & 3,8 \\
\hline Total & 26 & 100 & 26 & 100 \\
\hline \multicolumn{5}{|l|}{ 2. Ibu } \\
\hline Tidak bekerja & 0 & 0 & 0 & 0 \\
\hline Wirausaha & 1 & 3,8 & 0 & 0 \\
\hline Karyawan swasta & 0 & 0 & 0 & 0 \\
\hline PNS & 0 & 0 & 1 & 3,8 \\
\hline Wiraswasta & 0 & 0 & 1 & 3,8 \\
\hline Lain-lain & 25 & 96,2 & 24 & 92,3 \\
\hline Total & 26 & 100 & 26 & 100 \\
\hline \multicolumn{5}{|l|}{ Status Gizi } \\
\hline Normal & 0 & 0 & 26 & 50 \\
\hline Gemuk & 26 & 50 & 0 & 0 \\
\hline Total & 26 & 50 & 26 & 50 \\
\hline \multicolumn{5}{|l|}{ Besar Uang Saku } \\
\hline$<\operatorname{Rp} 15.000$ & 2 & 7,7 & 7 & 26,9 \\
\hline $\begin{array}{l}\text { Rp 15.000 - < Rp } \\
20.000\end{array}$ & 9 & 34,6 & 6 & 23,1 \\
\hline $\begin{array}{l}\text { Rp } 20.000-<R p \\
25.000\end{array}$ & 7 & 26,9 & 7 & 26,9 \\
\hline $\begin{array}{l}\text { Rp } 25.000-R p \\
50.000\end{array}$ & 8 & 30,8 & 6 & 23,1 \\
\hline Total & 26 & 100 & 26 & 100 \\
\hline \multicolumn{5}{|l|}{ Aktivitas Fisik } \\
\hline Ringan & 11 & 42,3 & 0 & 0 \\
\hline Sedang & 3 & 11,5 & 8 & 30,8 \\
\hline Berat & 12 & 46,2 & 18 & 69,2 \\
\hline Total & 26 & 100 & 26 & 100 \\
\hline
\end{tabular}

Namun penggunaan uang tersebut paling banyak digunakan untuk membeli makanan dan minuman, baik pada saat jam istirahat sekolah, sebelum masuk dan saat istirahat les, terkadang pada saat pulang sekolah maupun pulang les para siswi tetap menyempatkan membeli makanan kecil ataupun minuman disupermarket terdekat. Penelitian sebelumnya menjelaskan adanya korelasi antara frekuensi konsumsi makanan cepat saji dengan uang saku, dengan semakin besarnya uang saku yang diberikan maka akan semakin tinggi pula frekuensi konsumsi 
makanan cepat saji ${ }^{19}$. Penelitian lain juga menunjukkan tidak adanya perbedaan uang jajan pada responden dengan status gizi overweight dan non overweight di SMK Muhammadiyah 2 Surakarta hal ini dikarenakan uang saku atau uang jajan yang dibelanjakan pada makanan dikantin hampir sama dengan porsi yang sama baik pada kelompok overweight dan non overweight dengan nilai $\mathrm{p}$ $=0,185^{20}$. Pada penelitian lain terdapat hubungan besaran uang saku dengan kejadian gizi lebih pada anak sekolah dengan nilai $p=0,023$, dalam penelitian tersebut dinyatakan bahwa semakin tinggi atau besar uang saku yang diterima semakin pula besar daya beli seorang individu tersebut, dimana pengeluaran konsumsi makanan dipengaruhi oleh tingginya uang saku seseorang ${ }^{21}$. Pada penelitian ini tidak ditemukan perbedaan uang saku antara dua kelompok, hal ini disebabkan oleh selisih besar uang saku antara kedua kelompok sebesar Rp 1.231. Hal ini sejalan dengan penelitian sebelumnya yang menyatakan bahwa tidak adanya hubungan dari jumlah uang saku dengan kejadian masalah status gizi, dalam penelitian tersebut diketahui bahwa uang saku yang telah diterima oleh siswa dapat dibelanjakan berbagai macam makanan tanpa memperdulikan makanan tersebut bergizi ataupun tidak bergizi $^{22}$. Begitu juga dengan penelitian lainnya yang menyatakan bahwa tidak terdapat hubungan antara jumlah uang saku dengan status gizi, hal ini dikarenakan para murid tidak selalu menghabiskan uang saku yang diberikan untuk membeli jajanan saja, melainkan sebagian besar dari jumlah uang saku tersebut di alokasikan untuk ditabung, sehingga berapapun besar kecilnya uang saku yang didapat belum tentu akan mempengaruhi status gizi para murid ${ }^{23}$. Terdapat penelitian lain yang menunjukkan bahwa besarnya penggunaan pada uang saku yang digunakan untuk membeli jajanan memiliki hubungan dengan terjadinya gizi lebih, hal ini dikarenakan uang saku sebagai faktor atau penentu tingginya daya beli terhadap jajanan, makanan dan minuman pada saat mereka diluar rumah, sehingga semakin tinggi atau banyak uang saku yang dimiliki maka semakin besar pula daya atau kemampuan dalam membeli makanan tersebut yang dapat mendorong responden untuk mengonsumsi makanan secara berlebih, kecenderungan membeli makanan diluar rumah terkadang tidak memperhatikan apakah makanan tersebut memiliki gizi seimbang maupun tidak, kesalahan dalam pemilihan makanan dapat mempengaruhi status gizi²4.

Tabel 2 Perbedaan Besar Uang Saku Pada Siswi di SMA Negeri 5 Surabaya Tahun 2019

\begin{tabular}{ccccc}
\hline Uang Saku & Kasus Mean \pm SD & Kontrol Mean \pm SD & Nilai p $^{*}$ & OR \\
\hline Besar Uang Saku & $20.808 \pm 8997,86$ & $19.577 \pm 10253,47$ & 0,3800 & 1,364 \\
\hline
\end{tabular}

Pada Tabel 3 menampilkan data distribusi gambaran aktivitas fisik. Hasil penelitian menyatakan bahwa kelompok kontrol lebih banyak menghabiskan waktu untuk melakukan aktivitas fisik dengan rata-rata 31,5 (jam) dalam satu hari. Hasil wawancara pada saat pengambilan data penelitian terkait aktivitas fisik, siswi pada kelompok kasus bercerita bahwa saat pulang sekolah para siswi jarang untuk langsung pulang kerumah, melainkan terdapat kegiatan lain yang sudah menunggu seperti halnya les atau bimbingan belajar lain, terdapat beberapa siswa mengikuti dua bimbingan les Pada kelompok kasus total rata-rata durasi aktivitas fisik dalam satu hari adalah 23,36 (jam), dimana para siswi banyak menghabiskan waktu mereka untuk berada di dalam ruangan saja. Saat pulang dari sekolah, beberapa dari siswi dalam kelompok ini ada yang langsung pulang kerumah dan ada yang langsung berangkat ketempat bimbingan les. Aktivitas fisik yang dilakukan pada saat sudah tiba dirumah adalah berganti pakaian, beribadah dan tidur siang. Sedangkan pada sore harinya beberapa siswi ada yang berangkat menuju ke lokasi bimbingan les dan ada juga yang tetap berada dirumah dengan melakukan aktivitas fisik sepeti duduk santai, menonton tv atau film, bermain hp, makan minum dan mandi dan juga melakukan kegiatan rumah tangga lainnya seperti menyapu dan mengepel. Pada saat malam hari aktivitas fisik yang dilakukan adalah beribadah, mengerjakan pr dan tidur.

Tabel 4 menampilkan nilai total energi ekspenditur (TEE). Hasil dari uji beda di dapatkan nilai $p=$ ditempat yang berbeda dalam satu hari. Selain itu beberapa siswi juga mengikuti ekstrakulikuler baik disekolah maupun dalam sekolah seperti dance, bola basket dan renang. Pada saat para siswi sampai dirumah mereka melanjutkan untuk mengerjakan tugas sekolah ataupun kegiatan rumah tangga lainnya seperti mencuci piring, menyapu dan ada pula yang berkebun. Selebihnya aktivitas fisik lain yang dilakukan adalah menonton tv, bermain $\mathrm{hp}$, beribadah, menyiapkan buku untuk pelajaran sekolah esok hari, duduk santai, makan dan minum, membersihkan diri dan tidur.

0,00 yang diartikan sebagai terdapat perbedaan pada nilai total energi ekspenditur dari kedua kelompok. Hasil menunjukkan bahwa rata-rata nilai TEE pada kelompok kasus lebih kecil bila dibandingkan dengan kelompok kontrol. Bila dilihat dari hasil physical activity level (PAL), kelompok kasus cenderung memiliki aktivitas fisik dalam kategori ringan dan berat, sedangkan pada kelompok kontrol cenderung memiliki aktivitas fisik sedang hingga berat. Hasil penelitian ini sejalan dengan penelitian sebelumnya yang menyatakan bahwa terdapat perbedaan aktivitas fisik antara kelompok siswi dengan overweight dan tidak overweight ${ }^{25}$. Kelompok kasus memiliki status aktivitas fisik ringan (42,31\%) dari 26 siswi, maka dapat disimpulkan bahwa kelompok kasus cenderung tidak banyak melakukan pergerakan tubuh, lebih suka didalam ruangan. Sedangkan pada kelompok kontrol memiliki status aktivitas fisik sedang $(30,77 \%)$ dan berat $(69,23 \%)$ dengan berbagai macam aktivitas fisik atau kegiatan yang membutuhkan pergerakan tubuh 
seperti dance, bermain bola basket, les, dan melakukan pekerjaan rumah tangga seperti menyapu, mencuci piring, mengepel lantai dan berkebun. Penelitian sebelumnya menemukan bahwa adanya hubungan antara aktivitas fisik dengan kejadian obesitas di kalangan remaja SMP dan SMA. Pada kelompok murid yang jarang melakukan gerakan badan atau aktivitas fisik yaitu seperti olahraga akan memiliki tingkat resiko terjadi obesitas lebih tinggi apabila dibandingkan dengan kelompok murid yang sering melakukan gerak badan atau olahraga. Terdapat 1,5 kali resiko lebih besar untuk mengalami obesitas pada siswi yang jarang melakukan aktivitas fisik bila dibandingkan dengan murid yang melakukan aktivitas fisik kategori sedang hingga berat ${ }^{26}$. Penelitian lain menyatakan bahwa adanya hubungan antara aktivitas fisik dengan status gizi. Remaja yang jarang melakukan aktivitas fisik dalam kehidupan sehari-hari dapat meningkatkan berat badannya ${ }^{27}$. Terdapat hubungan antara aktivitas fisik dengan status gizi lebih yang terjadi di SDN Ketabang 1 Kota Surabaya Tahun 2017 dimana anak dengan aktivitas fisik rendah memiliki nilai indeks massa tubuh lebih dari normal dan beresiko mengalami gizi lebih, hal ini dapat disebabkan karena pengaruh dari ketidak seimbangan asupan energi yang telah masuk kedalam tubuh dengan energi yang dikeluarkan. Ketidak seimbangan ini dapat dipengaruhi pula oleh gaya hidup dengan tingginya konsumsi makanan tinggi kalori, lemak dan kolesterol yang tidak diimbangi dengan aktivitas fisik sehingga hal ini berdampak pada masalah gizi lebih ${ }^{28}$. Penelitian lain menunjukkan bahwa terdapat hubungan mengenai aktivitas fisik dengan status gizi, salah satu faktor yang dapat mempengaruhi status gizi yaitu aktivitas fisik dimana ketika asupan energi yang telah masuk tidak diimbangi dengan pengeluaran energi yang tidak seimbang hal itu dapat menyebabkan terjadinya kenaikkan berat badan ${ }^{29}$.

Tabel 3. Gambaran Aktivitas Fisik Siswi SMA Negeri 5 Surabaya 2019

\begin{tabular}{|c|c|c|c|c|}
\hline \multirow{3}{*}{ Jenis Aktivitas } & \multicolumn{4}{|c|}{ Kelompok Status Gizi } \\
\hline & \multicolumn{2}{|l|}{ Kasus } & \multicolumn{2}{|c|}{ Kontrol } \\
\hline & Durasi (jam) & Rata-rata (jam) & Durasi (jam) & Rata-rata (jam) \\
\hline \multicolumn{5}{|c|}{ Kegiatan personal: } \\
\hline 1. Tidur & 180 & 6,92 & 172 & 6,62 \\
\hline 2. Berbaring & 0 & 0 & 0 & 0 \\
\hline 3. Berpakaian & 4,95 & 0,19 & 4,90 & 0,19 \\
\hline 4. Kebersihan Diri & 12,84 & 0,49 & 7,36 & 0,28 \\
\hline 5. Makan Minum & 28,98 & 1,11 & 29,52 & 1,13 \\
\hline 6. Menulis & 18,5 & 0,71 & 20 & 0,77 \\
\hline 7. Berjalan & 0 & 0 & 0 & 0 \\
\hline 8. Belajar & 240,5 & 9,25 & 245 & 9,42 \\
\hline 9. Membaca & 0 & 0 & 0 & 0 \\
\hline 10 Olahraga & 0 & 0 & 8 & 2,66 \\
\hline 11. Ibadah & 18,9 & 1,05 & 19,85 & 0,94 \\
\hline 12. Bersepeda & 0 & 0 & 0 & 0 \\
\hline 13.Bersepeda Motor & 19,35 & 0,59 & 17,6 & 0,68 \\
\hline 14. Melukis & 0 & 0 & 0 & 0 \\
\hline 15. Berlari & 0 & 0 & 0 & 0 \\
\hline 16. Menari & 0 & 0 & 4 & 2 \\
\hline 17. Bermain Kartu & 0 & 0 & 0 & 0 \\
\hline 18. Berdiri & 8,95 & 0,34 & 10,26 & 0,38 \\
\hline 19. Duduk & 0 & 0 & 0 & 0 \\
\hline 20. Menonton tv / film & 34 & 1,31 & 38,5 & 1,48 \\
\hline \multicolumn{5}{|c|}{ Kegiatan Rumah Tangga: } \\
\hline 1. Menyapu & 48 & 0,36 & 1,02 & 0,38 \\
\hline 2. Berkebun & J & 0 & 3 & 3 \\
\hline 3. Mencuci Baju & ,75 & 0,88 & 4,5 & 0,94 \\
\hline 4. Mencuci Piring &, 5 & 0,17 &, 34 & 0,21 \\
\hline 5. Mengepel & 57 & 0,33 &, 01 & 0,35 \\
\hline Total & 612,27 & 23,36 & 628,86 & 31,05 \\
\hline
\end{tabular}

Kelebihan dari penelitian ini adalah adanya gambaran aktivitas fisik yang disertai dengan durasi waktu guna untuk melihat jenis aktivitas fisik apasajakah yang dilakukan oleh kedua kelompok responden, hal ini membantu peneliti untuk menganalisis mengapa ada perbedaa dari kedua kelompok tersebut. Kelemahan dalam penelitian adalah jumlah subyek yang terbatas, dikarenakan pada saat penelitian dilakukan beberapa kelas sedang melakukan ujian, sehingga hasil penelitian kurang dapat digeneralisasikan. Terdapat kendala pada saat dilakukan pengukuran tinggi badan, yaitu tidak ada nya permukaan dinding yang rata, lalu tidak ada pengait untuk memasang microtoise. Berdasarkan dari kelemahan dalam penelitian ini, disarankan pada saat akan turun lapangan sebaiknya memastikan situasi dan kondisi terlebih dahulu, sehingga proses pengambilan data dapat berjalan lancar. Lalu, sebaiknya pada saat akan melakukan pengukuran tinggi badan baiknya dilakukan 
ditempat yang layak seperti di ruang unit kesehatan sekolah (UKS), sehingga alat dapat terpasang dengan baik dan benar. Untuk dampak kebijakan dalam penelitian ini adalah diharapkannya ada aktivitas fisik tambahan seperti senam bersama yang dapat dilakukan 1 sampai 2 kali dalam seminggu, sehingga dapat membantu meningkatkan aktivitas fisik guna menjaga dan menurunkan berat badan.

Tabel 4. Perbedaan Aktivitas Fisik Pada Siswi di SMA Negeri 5 Surabaya Tahun 2019

\begin{tabular}{l}
\multicolumn{1}{c}{ Aktivitas Fisik } \\
\hline $\begin{array}{l}\text { Total Energi } \\
\text { Ekspenditur (TEE) kkal }\end{array}$ \\
\hline KESIMPULAN \\
Hasil dari penelitian ini menunjukkan tidak \\
adanya perbedaan besaran uang saku antara kelompok \\
kasus dan kontrol. Namun terdapat perbedaan aktivitas \\
fisik antara kelompok kasus dan kontrol. Maka dari itu \\
perlu dilaksanakan aktivitas fisik tambahan seperti senam \\
agar kelompok kasus dapat lebih menggunakan energi \\
mereka untuk bergerak dan diharapkan dapat mencegah \\
masalah gizi lainnya.
\end{tabular}

\section{ACKNOWLEDGEMENT}

Penulis mengucapkan terima kasih kepada seluruh responden penelitian dan enumerator, Badan Kesatuan Bangsa dan Politik Kota Surabaya, Dinas Pendidikan Kota Surabaya, SMA Negeri 5 Surabaya yang telah memberikan ijin dan membantu berjalannya proses penelitian ini, dan seluruh dosen Program Studi Gizi Fakultas Kesehatan Masyarakat Universitas Airlangga beserta staff, terkhusus kepada dosen pembimbing sehingga dapat terselesaikannya penelitian ini.

\section{REFERENSI}

1. Akhriani, M., Fadhilah, E. \& Nila Kurniasari, F. Indonesian Journal of Human Nutrition Hubungan Konsumsi Minuman Berpemanis dengan Kejadian Kegemukan pada Remaja di SMP Negeri 1 Bandung (Correlation of Sweetened-Drink Consumption with Obesity Prevalence in Adolescence in State Secondary School 1 Bandung). Indones. J. Hum. Nutr. 3, 29-40 (2016).

2. Kemenkes. Profil keshatan indonesia. kementrian Republik Indonesia. (2012).

3. World Health Organization. Imported from https://www.who.int/news-room/factsheets/detail/obesity-and-overweight. (2016). Available at: https://www.who.int/newsroom/fact-sheets/detail/obesity-andoverweight.

4. Kementerian Kesehatan RI. riset kesehatan dasar 2013. (2013).

5. KESEHATAN PROVINSI JAWA TIMUR JI Ahmad Yani, D. PROFIL KESEHATAN PROVINSI JAWA TIMUR TAHUN 2016.

6. Putra, W. N. \& Wahyuni, C. U. HUBUNGAN POLA MAKAN, AKTIVITAS FISIK DAN AKTIVITAS SEDENTARI DENGAN OVERWEIGHT DI SMA NEGERI 5 SURABAYA The Association Between Dietary Pattern, Physical Activity, Sedentary Activity And Overweight at SMA Negeri 5 Surabaya. doi:10.20473/jbe.v5i3.2017
7. Kurdanti, W. et al. Faktor-faktor yang mempengaruhi kejadian obesitas pada remaja Risk factors for obesity in adolescent. Jurnal Gizi Klinik Indonesia 11, (2015).

8. Ayu Dewi Sartika Departemen Gizi Kesehatan Masyarakat, R. \& Kesehatan Masyarakat, F. FAKTOR RISIKO OBESITAS PADA ANAK 5-15 TAHUN DI INDONESIA. JUNI 15,

9. $\quad$ Fiqriyah, R., Wahyono, H. \& Inayati, U. Pengelolaan Uang Saku, Pengaruh Emosional, Kecerdasan Pemahaman Dasar Ekonomi Terhadap Rasionalitas Perilaku Konsumsi Siswa Kelas IIS MAN, dan X. JPE 9, (2016).

10. Yosi, A. \& Wahyudi, H. PENGARUH UANG SAKU DAN GAYA HIDUP TERHADAP MINAT MENABUNG Studi Kasus: Mahasiswa Fakultas Ekonomi Universitas Sanata Dharma.

11. Zuhdy, N. HUBUNGAN POLA AKTIVITAS FISIK DAN POLA MAKAN DENGAN STATUS GIZI PADA PELAJAR PUTRI SMA KELAS 1 DI DENPASAR UTARA. (2015).

12. Irianto, K. Seimbang dalam kesehatan reproduksi 1st ed. Alfabeta (2014).

13. Wiraida, E. A. Perbedaan Tingkat Konsumsi Energi, Aktivitas Fisik Dan Pengeluaran Uang Jajan Pada Anak Sekolah Dasar Overweight dan Non Overweight di Wilayah Puskesmas Banjarejo, Kecamatan Taman Kota Madiun. J. Univ. Muhammadiyah Surakarta 1, 1-11 (2014).

14. Septiani, R., Raharjo, B. B. \& Artikel, I. Pola Konsumsi Fast Food, Aktivitas Fisik dan Faktor Keturunan Terhadap Kejadian Obesitas (Studi Kasus pada Siswa SD Negeri 01 Tonjong Kecamatan Tonjong Kebupaten Brebes). Public Heal. Perspect. J. 2, 262-269 (2018).

15. Kandinasti, S. perbedaan asupan zat gizi makro dan berat badan saat weekdays dan weekend pada remaja di sman 5 surabaya. universitas airlangga (2018).

16. Suhardjo, . sosial budaya gizi. Institut Pertanian Bogor (1989).

17. Putri, R. M. et al. KAITAN PENDIDIKAN, PEKERJAAN ORANG TUA DENGAN STATUS GIZI ANAK PRA SEKOLAH. Jurnal Care 5, (2017).

18. Husain, A., Tendean, L. \& De Queljoe, E. PENGARUH KELEBIHAN BERAT BADAN / OVERWEIGHT TERHADAP TERJADINYA DISFUNGSI SEKSUAL PRIA. Jurnal e-Biomedik $(e B m)$ 3,

19. Imtihani, T. R. \& Noer, E. R. HUBUNGAN 
PENGETAHUAN, UANG SAKU, DAN PEER GROUP DENGAN FREKUENSI KONSUMSI MAKANAN CEPAT SAJI PADA REMAJA PUTRI. J. Nutr. Coll. 2, 162-169 (2013).

20. Astuty, R. T. perbedaan asupan serat dan besar uang saku antara status overweight dan non overweight pada siswa smk muhammadiyah 2 surakarta. universitas muhammadiyah surakarta (2016).

21. Teman, H. P. et al. Relationship between the role of friends, the role of parents, pocket money and perception of snack with overweight incidence. Amerta Nutr 30-36 (2018). doi:10.2473/amnt.v2i2.2018.189-196

22. Putri, K. A. hubungan pengetahuan gizi, jumlah uang saku dan kebiasaan konsumsi fast food dengan status gizi pada siswa smpn 25 surakarta. universitas muhammadiyah surakarta (2017).

23. Muliawati, R. R. HUBUNGAN PENGETAHUAN MEMILIH MAKANAN JAJANAN DAN JUMLAH UANG SAKU DENGAN STATUS GIZI SISWA SD NEGERI KLECO II SURAKARTA. (2018).

24. Rosyidah, Z., Ririn Andrias, D. \& Gizi Kesehatan Fakultas Kesehatan, D. Jumlah Uang Saku Dan Kebiasaan Melewatkan Sarapan Berhubungan Dengan Status Gizi Lebih Anak Sekolah Dasar.
1-6 (2013).

25. Mahmudah, H. perbedaan aktivitas fisik antara remaja putri yang overweight dengan non overweight di smp muhammdiyah 10 surakarta. universitas muhammadiyah surakarta (2014).

26. Restuastuti, T., Jihadi, M. \& Ernalia, Y. Hubungan Pola Makan Dan Aktivitas Fisik Terhadap Obesitas Pada Remaja Di SMA Negeri 5 Pekanbaru. Jom FK 3, (2016).

27. Khasanah, D. hubungan aktivitas fisik dengan status gizi remaja putri di pondok pesantren ta'mirul islam surakarta. Univ. muhammadiyah (2016).

28. Dayinta, N., Ermona, N. \& Wirjatmadi, B. Hubungan Aktivitas Fisik Dan Asupan Gizi Dengan Status Gizi Lebih Pada Anak Usia Sekolah Dasar Di Sdn Ketabang 1 Kota Surabaya Tahun 2017 Relationship between Physical Activity, Nutrition Intake and Overweight Status among Elementary School Student in SDN Ketabang 1 Surabaya 2017. Amerta Nutr 12-15 (2018). doi:10.2473/amnt.v2i1.2018.97-105

29. Delimasari, A. Hubungan Pola Aktivitas Fisik Dengan Status Gizi Pada Mahasiswa Prodi Div Bidan Pendidik Universitas ‘ Aisyiyah Gizi Pada Mahasiswa Prodi Div Bidan Pendidik Universitas 'Aisyiyah. J. Unisa 1-7 (2016). 